\title{
The Influence of the Political Regime on Property Rights in Post-Soviet Russia
}

\author{
Andrey Marin-Ostrovskiy \\ Candidate of Political Sciences \\ National Research University Higher School of Economics, Russia \\ Email:m-ostrovsky@yandex.ru
}

\section{Doi:10.5901/mjss.2013.v4n10p241}

\begin{abstract}
Security degree and specification level of property rights are keys for successful economic and social modernization in Russia. In the research, the attempt of evaluating the nature of political influences on evolution of property rights is made. Chronologically research captures the period from 1985 (period of Perestroika) to 2012. According to the author's claim, such political parameters, as the way of power legitimation, actors' access to the economic, military and symbolical resources, made major impact on the formation of property rights in Russia.
\end{abstract}

Key words: property, property rights, political regime, institutional changes, Russia.

\section{Introduction}

The goal of the research is the search of the method, which allows investigating the connection between the political and economic dimensions. We believe the roots of the economic problems in modern Russia are in specific features of the property institute, which are in turn determined by the particular qualities of the political regime.

\section{Literature review}

At the moment, there are several theoretical and empirical research promises, which are at the steam of the neoinstitutionalism. First one is the statement of the institutional significance (North, 1990).

Second one is the statement, that one of the key parameters, which forms the type of activity of the economic agents, is the property rights. By this moment the foundation of neoinstitutional understanding of the property rights have been laid (Demsetz, 1967; Alchian and Demsetz, 1972, 1973; Alchian 1974, 1984).Questions of the structural organization of property rights system have been solved (Honore, 1961). Only in presence of objectively protected property rights individuals and organizations have the incentives for highly productive activities, because they have rights for the end results of their activities, which cannot be reallocated between the parties, that have not participated in the generation of those results. The high degree of the property rights specification is also considered to be very important, as this is the only way to achieve maximal interaction of rights exchange between different parties.

Third is the statement of the high political influence on the economic processes in Russia (Bessonova, 2006; Gaidar, 1995; Kryshtanovskaya, 2005; Pappe and Galuhina, 2009; Pappe, 2000; Tambovcev, 2009).

Nevertheless, today there are no answers for the large range of questions. First, the character of the political influence on the economic spheres and processes is not clear. Especially, this is relevant for the countries with the dynamically developing political regimes, which are in the process of transformation (this can be attributed to Russia). Second, mechanisms of the interaction of the political and economic institutes are not clear. In the research the system of the property rights is considered as an integrated institute, which mediates the interaction of the economic and political institutes. Third, at the moment the principles of the internal organization of the institutional sphere are not clear, in other words how different rules and norms interact and are subordinated between each other.

\section{Problem}

The problem of the research is the lack of scientifically relevant and methodologically correct criteria, parameters and classifications, which permits objective estimation of the phenomenon of political regime influence on the transformation of the property institute in the post-Soviet Russia. 


\section{Methodology}

\subsection{Theoretical approach}

The research is conducted in the scope of the neoinstitutional approach, which is interpreted as one of the particular options of the methodology of new political economy. The boundaries between different variations of the new institutionalism are not considered to be rigid. In this regard, the research is constructed on the basis of the historical institutionalism methodology with the usage of rational choice institutionalism and constructivist institutionalism elements. Our methodological postulates:

- Institutes are considered to be "norms and rules", not equilibriums (Schotter, 1981).

- The dynamics of the institutional transformations is determined by the path of the past development and also by the decisions of players - the choice of actors in the key historical periods.

- Focusing on the key points of change, while studying institutional changes.

- "Cumulative" and "cultural" models of actor's behavior.

- Actors can be individual or collective; second ones can also act in the form of network structure.

\section{Data Collection}

The research is based on conducted desk studies with the usage of secondary sources. Database is introduced by: the statistical data of the federal agency of Russian state statistics, the Court of Auditors of Russian Federation reports, internet and paper media sources, data, presented on the official governmental web-sites.

\section{Research hypotheses}

$\mathrm{H} 1$ - The required defense of the property rights is not provided in modern Russia, property rights are not specified at the proper degree.

$\mathrm{H} 2$ - Modern political regime in Russia has a range of particular features, which determine the transformation of the property institute, i.e. the change if the property rights structure.

H3 - From 1985 till 2010 the property institute and also the political regime, had a set of features. The changes of both political regime and characteristics of property rights have been synchronous.

\section{Basic concepts}

Institutes and the problem of guarantor. We consider institutes to be the rules of the game and the forcing mechanisms of maintaining the obedience those rules (North, 1990). Any rule suggests the presence of forcing mechanism to follow the rules. Therefore, as forcing cannot be impersonal, guarantor and rules are necessary (Auzan, 2006). Government, any force structure and also the target of the rule can represent the guarantor (Volkov, 2002). Nevertheless, the degree of its performance depends on the guarantor, and by rejecting its rules, guarantor can stop its existence. Wherein guarantor is also an actor and the only difference from the other actors is that ideally it has to provide the defense of the rules and norms. Similarly to other players, guarantor is not under the system, but inside of it.

Institute functioning regime. By analyzing the features of institutional environment it is possible to outline elements of the hierarchical order in it. But, the clearest order is seen on the level of formal institutes, where the hierarchy of the sources of power is present (the term is commonly used in the jurisprudence). In most modern political systems the highest juridical power is held by the constitution, and all the legal conflicts are resolved in favor of constitution. Nevertheless, in the real life we often see derogation from this rule, which is only strive for hierarchical order, not the rigidly hierarchical structure. Similar imperfect order is present in institutes also, which permits analyzing them as a special kind of institutional clusters - sets of functionally interrelated and relatively regulated norms and rules.

If we analyze the structure if the institutional clusters more carefully, we will see that together with the "firm core" goes a more flexible "shell". Elements of this "shell" much more compliant for the external impact, unlike the core, but the change in it can influence the functional course of the institute and its functioning regime.

Actors. In the classical researches, the special attention is given to the difference between the institutes and organizations (actors). In Russia, "players" could be clienteles ("clans", "clips", "families") and integrated business-groups (Pappe, 2000). Such structures are based on the network principle and have no clear structure, all the more so - this is 
attributable for those created in purpose, no clearly definable boundaries, and even understanding the goal of their function is not always easy to understand.

Strategies. Strategy is organized and serial sequence of actions, oriented on the achievement of a goal. We outline two types of strategies, which differ by the object of orientation: strategies for institutions (institutional strategies) and strategies for other actors. When analyzing the strategies of the second type we can use the scheme, which was introduced by (Sartori, 1987), who, regarding the possibility of dual interpretation of the politics, subdivided them on the strategies of "war" (the game with zero sum) and the "auction" (the game with the non-zero sum). Nevertheless in the context of institutional strategies a more complex classification is required. We outline three "clear" types of the institutional strategies (with the following division of both of them on the subtypes).

1. The strategy of the institutional changes, i.e. actions directed on reorganization of the present institutes:

- Individual (the situation, when actor has enough resources for the independent reorganization of the institute);

- Collective (the situation, when due to the lack of resources actor has to coordinate his strategies with the strategies of the other actors).

2. Strategy of the institutional submission, which means passive acceptance of the established norms and rules. This strategy contributes the consolidation of the existing institutes and, if those institutes are creating negative stimulus, its long-term consequence can become the disruption of the political and/or economic system in general.

3. Strategy of the institutional noncompliance, i.e. commitment of actions, which are beyond the borders of the existing rules, without the attempt to change those rules.

a) Strategy of accepting risks (the intruder can hope on the successful outcome, as the possibility of applying sanctions against the violations is never 100\%);

b) Strategy of changing the institutional functioning regime (influencing either the force mechanisms to follow the rules or the way of enforcement, for example mass disobedience, depriving the guarantor the possibility to use sanctions due to the lack of its resources).

Resources. In order to initiate any of the strategies, actors, limited by the institutional environment, need resources. Resource - is the attribute, circumstance or welfare, possessing which increases owner's ability to influence other individuals or groups. We can outline three types of resources: power, economic and symbolical.

Property rights. Property rights are a set of norms and rules, which regulate the capabilities of individuals and organizations to use limited resources and also mechanisms of those capabilities. Property rights (Demsetz, 1967; Alchian and Demsetz, 1972, 1973; Alchian 1974, 1984) can be observed on the macro-level, in the scale of the whole government and society and also in the scale of individual and corporation activity.

In the research we outline three basic parameters of the property rights:

1) The degree of the specification of the property rights (clear definition of the property object and subject, and also all the rights related to the possession of property).

2) The degree of the property rights defense (availability of the functioning mechanisms, which enable the defense of the objects of property from encroachment, including encroachment from government);

3) The degree of the management control (the full degree of the control over the property).

\section{Results}

\subsection{Mechanisms of property reallocation}

The specification and protection of property directly influences the domination of certain reallocation mechanisms. At high degree of specification and protection the highest distribution goes to the market and juridical mechanisms of property reallocation, in the other case - to the administrative or purely power mechanisms. In general, it is possible to outline five mechanisms of such reallocation:

- Economic (purchase, sale, leasing, rent);

- Juridical (voluntary or forced transfer of property on the conditions and forms established by the government).

- Force (taking over the property by directly using it or by threatening with the physical violence);

- Taxation (actual change of the property rights characteristics by setting the obligatory gratuitous payments to the state or other power structures); 
- Administrative (actual change of the property rights characteristics by using the ability of the government to influence on owners, acting under the set of legal rules);

- Managerial (setting the control over the activities of the enterprise through intrusion of "state people" into the leading positions of the enterprise or creating a chain of side organizations around it, which held key managerial functions: cash flow management, sales, e.t.c.).

\subsection{Mechanisms of property rights transformation in post-Soviet Russia}

The vast majority of models, which describe institutional changes more or less focus on the exogenous in the relation to the institutional environment factors - for example, prices on the resources (Demsetz, 1967) or the level of knowledge (North, 1990) - moving of which leads to the institutional transformations. However, such explanations can be considered sufficient only in a long-term perspective and only in relation to a relatively stable and effective environment with the arrangement of actors, i.e. by following the conditions, which are lacking in the post-Soviet Russia.

In our opinion, in the Russia's case the dynamics of the transformation of the property institute have been determined and will be determined by the sequence of the situational decisions of the key actors.

During the period of existence of post-Soviet Russia there have always been two key players: "state" and "business". Of course, the division of the groups is in some extend arbitrary. First, neither state subjects, nor the subjects of the private business are clearly institutionalized. Second, the boundaries of those subjects are highly vague and are not always easily defined, all the more so during the last 15-20 years we have witnessed the apparent diffusion of the "state power" into "business" and "business" into "state power". The "state power" is organized as a kind of a collection of clienteles (Afanasiev, 2000), and the key business-actors can be identified with the financial and institutional group, or integrated business-groups (Pappe, 2000).

It is possible to take for granted, that any political player will be trying to maximize his power and influence. There are three ways to solve this problem: forcing (power resource), encouraging (economic resource) and persuasion (symbolic resource). Similarly, any business-sector, by definition, strives for increasing its capital.

Now we can define the mutual interests of the "state power" and "business". Analyzing the interest of the "state power" in "business", we defined the two groups of interests. First one is connected with the implementing of social security functions. In comparison to the countries with the developed market democracy, where those functions have been always implemented by the government through tax receipts, in Russia from the Soviet times there have been practice of shifting those functions to the responsibility of the economic entities. With the collapse of the Soviet system the need of "state power" in attracting such structures (in the face of "business") for solving social issues have not decreased, but even increased significantly.

The second group of interests can be roughly described as a collection of political rents. The electoral institute had been formed after the political transition in Russia, the presence of the politician in the power hierarchy began to depend on his ability to achieve the electoral support. But for the organization of the effective electoral campaign significant financial resources were needed, which could be provided only by the "business", because even politicians, who had the access to the large amount of the resources of the government (such as governors), didn't have a possibility to use them directly to resolve their electoral problems.

Things are getting even more interesting in the case of the "business". Due to the fact that the government is not interested in creating the highly-effective property institute, which inevitably hardens the collection of the political rent, the demand for the establishment of a more specified property rights system could come only from "business". But there was no demand. Such situation was apparently due to some circumstances. First, the "blurry" property institute allowed implementing a hidden "privatization of income" of companies, which have still been in the hands of the government. Second, quite real competitive advantages, which were acquired by the business-actor, who in turn have already established the connections with the political players, were pushing them to make a stake on strengthening their cooperation with the state at the expense of enlarging the "formal-institutional" safety. Third, the appearance of the highly-specialized property institute would damage "the examination" by the "business" of the vast array of unallocated "state property". Fourth, the sustainable property institute demanded social legitimization, but business-actors have always had problems with that. In general, the conjunctural interests of the "business" took precedence over structural, preventing the realization the potential threat from the government and to understand how important is the specified system of the property rights from the point of long-term revenue.

If to talk about strategies of "business" and "state power" we can see that they are not very diverse. The main strategy of power actors is the strategy of institutional changes, which consists in constant displacement of the business- 
actors to the "grey-zone", in other words the creation of such formal rules, which makes it impossible engage in any other entrepreneurial activity, making "business" violate legislation, and then to adjust "special" relationships with the governmental officials. The most representative is the tax system of the Russian Federation (Yakovlev, 2007). In addition to that, we need to note that such strategy is not fully realized and its dominance was partly due to the mistakes which were made during the political decisions.

Business-actors, in turn, have been using the strategy of the institutional disobedience either just taking all the risks or trying to change the institutional functioning regime (first of all, through the individual agreements with the "state power").

The result of such interaction of the "state power" and "business" was the creation of poorly specified property institute. This is supported by the series of high-profile litigations (the Yukos affair, "RussNeft", "Mechel", TNK-BP, etc.). The institute have not changed in comparison with the beginning of the 1990s, although over the past decade and a half its functioning regime have been rebuild for several times.

\subsection{Property institute functioning regimes}

As of two groups, the initiative and the advantage in terms of resources was carried by the actors in power, who had to fulfill the functions of guarantor together with their own goals, the core element in the typology of the regimes of property institute functioning below is actors in power. According to our hypothesis, the characteristics of the property institute depend on the way power actors secured the legitimacy of their organizational structures and forms of interaction with other players. Accordingly, we have the following set of the classification criteria:

1) The type of organizational structure (degree of institutionalism);

2) The way to legitimize power

3) The composition of actors (presence of other relevant actors, the specificity of interaction with them);

During the struggle of achieving their goals, actors compete for resources, because even using the right strategy will not give any result without the required resource base. The resources are allocated in certain organization, which means the control over those organizations leads to the control over resources. The best opportunity to put pressure on the opponent gives the control over such organizations as the media, political parties and pressure groups, bureaucratic (state) apparatus and power structures, i.e. the organizations which carry functions of the instrument, and using them is the way to interact with the key players.

The analysis of transformations, which took place in Russia from the end of 1980s, allows us to emphasize three functioning regimes of the property institute: administrative, bureaucratic and segmented. Also, for teleological reasons, we included one more regime type - the market-democratic, in the formation of which the majority of the researches see the end result of all the system transformations of the property institute in Russia. For convenience, the results of typology are presented in the tables (see table 1-4):

The market-democracy regime presupposes the presence of the institutionalized actor, who comes to power through competitive elections. In this regime the dominant power actor is limited by the juridical norms, and also by the influence of other political and business-players. He can use neither power structures, nor bureaucratic apparatus for maintaining power. Media is independent. The property rights are specified and protected well enough.

Table 1. Market-democracy property institute functioning regime

\begin{tabular}{|l|l|l|}
\hline Actors & Power actors & $\begin{array}{l}\text { 1) Institutionalized } \\
\text { 2) Electoral legitimacy } \\
\text { 3) Presence of many competing actors }\end{array}$ \\
\cline { 2 - 3 } & Business-actors & $\begin{array}{l}\text { Independent of power; Influence the policymaking only through the } \\
\text { official lobbing mechanisms ; interact with each other through the } \\
\text { mechanisms of the market competition }\end{array}$ \\
\hline \multirow{3}{*}{$\begin{array}{l}\text { Interaction } \\
\text { mechanisms }\end{array}$} & Media & Independent; functioning as the usual business-structures \\
\cline { 2 - 3 } & $\begin{array}{l}\text { Political parties and } \\
\text { pressure groups }\end{array}$ & $\begin{array}{l}\text { Independent; function as autonomous subjects of the political process; } \\
\text { perform the functions of articulation and aggregation of public interests }\end{array}$ \\
\cline { 2 - 3 } & $\begin{array}{l}\text { Bureaucratic } \\
\text { apparatus }\end{array}$ & $\begin{array}{l}\text { Autonomous from the power and business-actors; well-integrated and } \\
\text { organized ; low corruption level }\end{array}$ \\
\cline { 2 - 3 } & Power structures & $\begin{array}{l}\text { There are only governmental power structures (except some small } \\
\text { "dark" zones); autonomous from power and business-actors }\end{array}$ \\
\hline
\end{tabular}




\begin{tabular}{|l|l|l|}
\hline $\begin{array}{l}\text { Property } \\
\text { institute }\end{array}$ & Specification & $\begin{array}{l}\text { High specification; property titles are clearly defined; low transaction } \\
\text { costs }\end{array}$ \\
\cline { 2 - 3 } & Protection & $\begin{array}{l}\text { High protection; the dominance of legal and economic mechanisms of } \\
\text { redistribution, with limited use of the tax and administrative mechanisms }\end{array}$ \\
\cline { 2 - 3 } & Managerial control & High managerial control \\
\hline
\end{tabular}

Administrative regime in the way was formed in the USSR is quite well described in the literature (Kordonskiy, 2006; Bessonova, 2006) that's why we will not examine it in details. We will note, that it started to ruin from 1986, when the formal base for controlling the private business activity by the Komsomol was created.

In 1991 the law "On Privatization of State and Municipal Enterprises in the Russian Federation" was passed, which meant the change of the property institute itself, but not the functioning regime. Since then, the private property has appeared in the country. In the subsequent history there will be no such large-scale transformations. An important step in the process of the formation of the new institution was the adoption of the Constitution of the Russian Federation in 1993, where it was stated, that "the land and other natural resources may be in private, state, municipal and other forms of property." A final conclusion was the adoption of "the Civil Code of the Russian Federation" in 1994.

Table 2. Administrative property institute functioning regime

\begin{tabular}{|c|c|c|}
\hline \multirow[t]{2}{*}{ Actors } & Power actors & $\begin{array}{l}\text { 1) Institutionalized dominant actor } \\
\text { 2) The ideological legitimation } \\
\text { 3) The lack of alternative centers of power }\end{array}$ \\
\hline & Business-actors & $\begin{array}{l}\text { Absent as a subject that affects the policymaking; subordinated to } \\
\text { dominant actor through a specially created management structures }\end{array}$ \\
\hline \multirow{4}{*}{$\begin{array}{l}\text { Interaction } \\
\text { mechanisms }\end{array}$} & Media & Controlled by the power actor; perform tough manipulative influence \\
\hline & $\begin{array}{l}\text { Political parties and } \\
\text { pressure groups }\end{array}$ & Integrated with the dominating power actor \\
\hline & $\begin{array}{l}\text { Bureaucratic } \\
\text { apparatus }\end{array}$ & Integrated with the dominating power actor; " nomenclature" institute \\
\hline & Power structures & $\begin{array}{l}\text { There are only governmental power structures; subordinated to the } \\
\text { dominant power actor }\end{array}$ \\
\hline \multirow[t]{3}{*}{$\begin{array}{l}\text { Property } \\
\text { institute }\end{array}$} & Specification & $\begin{array}{l}\text { High specification; actually all property belongs to the state, " conjoined " } \\
\text { with the dominant actor; medium transaction costs }\end{array}$ \\
\hline & Protection & High protection \\
\hline & Managerial control & $\begin{array}{l}\text { Very low managerial control; lack of effective ways to solve the problem of } \\
\text { "principal-agent" }\end{array}$ \\
\hline
\end{tabular}

Segmented regime is characterized by the relative parity of forces of power and business actors. Dominating power actor is not institutionalized and is represented as clientele, referred as "the family" (Boris Yeltsin and his inner circle). Actively using the structured weakness of the "state power" and spitting, when needed, the "family" (removal of Alexander Korzhakov and Anatoly Chubais, after an unsuccessful tender for the privatization of "Svyazinvest"), "business" is promoting its projects.

The first severe blow to the government by "business" was in 1994, during the Chechen war, when the TV-channel NTV under the control of the "Gusinski group" started to publicly criticize Kreml' policy. At that moment the force superiority of the "power" was still undisputed, and it was demonstrated by the strike against the "Gusinski group". However, one and a half years later, during the presidential campaign in 1996 the "business" clearly demonstrated its ability to dictate the political course of the country. After 1996 "business" had not only purchased for almost nothing (in the framework of the second phase of the "loans for shares") the huge amount of assets, but also started the expansion to the "state power" very successfully, by getting a large number of the governmental portfolios.

Table 3. Segmented property institute functioning regime

\begin{tabular}{|l|l|l|}
\hline Actors & Power actors & $\begin{array}{l}\text { 1) Not institutionalized (the network principle of the organization) } \\
\text { 2) Charismatic leadership } \\
\text { 3) Asymmetrical composition of actors: one dominant and several } \\
\text { subordinated, but independent actors }\end{array}$ \\
\hline
\end{tabular}




\begin{tabular}{|l|l|l|}
\hline \multirow{7}{*}{$\begin{array}{l}\text { Interaction } \\
\text { mechanisms }\end{array}$} & Business-actors & $\begin{array}{l}\text { Closely intertwined with government actors; have an impact on "state } \\
\text { power" through media, financial and organizational resources, power } \\
\text { and administrative control methods }\end{array}$ \\
\cline { 2 - 3 } & $\begin{array}{l}\text { Media } \\
\text { Political parties and } \\
\text { pressure groups }\end{array}$ & $\begin{array}{l}\text { Financially and organizationally dependent on the "business" or on } \\
\text { the power of actors: often created for a specific project }\end{array}$ \\
\cline { 2 - 3 } & Bureaucratic apparatus & $\begin{array}{l}\text { Easily affected by both "business" and " state power"; atomized; high } \\
\text { levels of corruption }\end{array}$ \\
\cline { 2 - 3 } & Power structures & $\begin{array}{l}\text { Segmented; along with the governmental, there are "power } \\
\text { entrepreneurs" and power structures that belong to business actors }\end{array}$ \\
\hline Property institute & Specification & $\begin{array}{l}\text { Low specification; large business is organized in the form of IBG; } \\
\text { extremely high transaction costs }\end{array}$ \\
\cline { 2 - 3 } & Protection & $\begin{array}{l}\text { Low protection; power, tax, administrative and managerial } \\
\text { mechanisms of redistribution; the main threat for "business" is } \\
\text { "business" itself }\end{array}$ \\
\cline { 2 - 3 } & Managerial control & $\begin{array}{l}\text { Low managerial control; government barely manages its assets, } \\
\text { "business" is interfered by the structures of IBG }\end{array}$ \\
\cline { 2 - 3 }
\end{tabular}

Bureaucratic regime At the beginning of 2000s the progressive build-up by "business" of its resource strength was suddenly interrupted by the rapid strengthening of the power actor. In our opinion, this was due to a complex and favorable for the "power" of circumstances (a sharp decrease in the economic power of "business" after the crisis in 1998, the split of business actors in the rival groups, more expressed "social order" for strengthening the governmental power and "suppressing the oligarchs", and, finally, the presence of deprived, but a well-integrated group of" security forces " that have potentially significant resource and capable of providing personnel support for the power actor), the appearance of which allowed the power to take advantage of the Constitution of 1993 (which Yeltsin was not capable of). "Power" has consistently pursued a series of attacks on the "business" (elimination of Gusinsky's media empire, the elimination of Berezovsky and - as the climax - the destruction of YUKOS), implementing the strategy of institutional change and the suppression of alternative sources of "power", active usage of force and the administrative mechanisms of redistribution of property in favor of state-owned companies, which enables it to strengthen its positions in other fields (the federal reform, the creation of the "United Russia" and other loyal parties, changing the electoral formula, etc.). However, the degree of institutionalization of the dominant actor is extremely low, the overall mechanism of coordination of interests, acceptable even to the power hierarchy, is actually absent.

Table 4. Bureaucratic property institute functioning regime

\begin{tabular}{|c|c|c|}
\hline \multirow[t]{2}{*}{ Actors } & Power actors & $\begin{array}{l}\text { 1) Not institutionalized (the network principle of the organization) } \\
\text { 2) The populist mode of legitimation } \\
\text { 3) The suppression of alternative centers of power }\end{array}$ \\
\hline & Business-actors & $\begin{array}{l}\text { Partial autonomy, limited by system of "feeding"; mainly administrative } \\
\text { methods of dealing with the minimum market competition }\end{array}$ \\
\hline \multirow{4}{*}{$\begin{array}{l}\text { Interaction } \\
\text { mechanisms }\end{array}$} & Media & Controlled by the power actors; perform a soft manipulative influence \\
\hline & $\begin{array}{l}\text { Political parties and } \\
\text { pressure groups }\end{array}$ & Controlled by the power actors, using a broad administrative support \\
\hline & Bureaucratic apparatus & $\begin{array}{l}\text { Subordinated by the imperious actor; the average level of organization and } \\
\text { integration; corruption is transformed into the "feeding" system }\end{array}$ \\
\hline & Power structures & $\begin{array}{l}\text { Weight and the necessary resources have only government forces } \\
\text { subordinated to the dominant power actor, the other functions are reduced to } \\
\text { maintain the security system; "feeding" system }\end{array}$ \\
\hline \multirow[t]{3}{*}{ Property institute } & Specification & $\begin{array}{l}\text { Low specification; rights of legal owners are blurred by the controlling } \\
\text { authorities, the actual rights of which are not legally secured }\end{array}$ \\
\hline & Protection & $\begin{array}{l}\text { High in relation to the "business" and is extremely low in relation to the state; } \\
\text { the special role is given to the force and administrative mechanisms of } \\
\text { redistribution (along with the economic and legal mechanisms) }\end{array}$ \\
\hline & Managerial control & $\begin{array}{l}\text { Middle managerial control; the effective control of the assets by "business" is } \\
\text { hindered by the "feeding" system }\end{array}$ \\
\hline
\end{tabular}




\section{Conclusion}

1. Russian political regime has a fairly strong impact on the institutional environment, which defines social and economic dimensions of development. This potential is implemented not through a particular public policy, but through the interaction between the different actors. In other words, the institutional environment is not the result of deliberate institution-building, but of the political struggle.

2. Right now Russia has established a bureaucratic mode of operation of the institution of property with one dominant actor. However, the dominant actor is not omnipotent, because it is not institutionalized, and because of the "resistance of the environment," which means the residual capacity of the "business" and society to oppose an outside influence.

3. The dynamics of institutional change is not rigidly determined, and significant changes can be made as long as that the dominant actor gives up all individual strategies of institutional change and demonstrates a willingness to engage in public dialogue with "society" and "business."

We consider the last conclusion to be the most important. Today, nobody can impose any dialogue to the dominant actor, but he can still initiate it. At the moment, the dominant actor faces a simple choice: either to remain a sole-owner of the peripheral country, or by giving up some of his power trying to bring it into the position of the world leaders. All the cards are in the hands of "state power", but the low institutionalization leads to the paradoxical situation, when the dominant actor is capable of everything, but is not aware of his goals in the strategic term.

\section{References}

Afanasiev M. (2000) Clientelism and the Russian state. Moscow: MONF.

Alchian A. A. (1984) Specifity, specialization, and coalitions. Journal of Institutional and Theoretical Economics, 140 (1), 50-53.

Alchian A. A. (1974) Corporate management and property rights. The economics of property rights. Cambridge.

Alchian A. A., Demsetz H. (1972) Production, information costs, and economic organization. American Economic Review, 62 (6), 777795.

Alchian A. A., Demsetz H. (1973) The property rights paradigm. Journal of Economic History, 33(1), 16-27.

Auzan A.A. (2006) Institutional economics: new institutional economic theory. Moscow.

Bessonova O. (2006) Dispensing economy of Russia. Moscow.

Demsetz H. (1967) Toward a theory of property rights. American Economic Review. , 57( 2), 347-359.

Gaidar E.(1995) State and Evolution: Russia's Search. Moscow.

Hoffman D. (2002) The Oligarchs: Wealth and Power in the New Russia. New York: Perseus Book Group

Honore A. M. (1961) Ownership. Oxford essays in jurisprudence. Ed. by Guest A. W. Oxford: Oxford University Press.

Klebnikov P. (2000) Godfather of the Kremlin: Boris Berezovsky and the Looting of Russia, New York: Harcourt. inc.

Kordonskiy S. (2006) Administrative Markets in the USSR and Russia. Moscow.

Kryshtanovskaya O. (2005) An Anatomy of the Russian Elite. Moscow.

North D.C. (1990) Institutions, Institutional Change and Economic Performance. Cambridge: Cambridge University Press.

Pappe Y., Galuhina Y. (2009) Russian large business: the first 15 years. M.: HSE..

Pappe,Y. (2000). The Oligarchs. Moscow: HSE.

Sartori G. 1987. The Theory of Democracy Revisited. - New Jarsey: Chatham House Publishers Chatham.

Schotter A. (1981) Economic Theory of Social Institutions. Cambridge.

Tambovcev V. ed. (2009) Property rights, privatization and nationalization in Russia.

Volkov V. (2002) Violent Entrepreneurs: The Use of Force in the Making of Russian Capitalism. Ithaca, New York: Cornell University Press.

Yakovlev A. (2007) Agents of Modernization' monograph. Moscow: HSE. 